ISSN 1392-3196 / e-ISSN 2335-8947

Zemdirbyste-Agriculture, vol. 104, No. 4 (2017), p. 329-336

DOI 10.13080/z-a.2017.104.042

\title{
The influence of composts on potato tuber, spring oilseed rape seed and threshing residue yields and concentrations of chemical elements in them
}

\author{
Gediminas STAUGAITIS ${ }^{1}$, Ieva NARUTYTE ${ }^{1}$, Jonas ARBAČAUSKAS ${ }^{1}$, \\ Zigmas VAIŠVILA ${ }^{1}$, Kęstutis RAINYS ${ }^{2}$, Romas MAŽEIKA ${ }^{1}$, Aiste MASEVIČIENÉ ${ }^{1}$, \\ Lina ŽIČKIENE $\dot{E}^{1}$, Donatas ŠUMSKIS ${ }^{1}$, Karolina GVILDIENE ${ }^{1}$
}

\author{
${ }^{1}$ Agrochemical Research Laboratory, Lithuanian Research Centre for Agriculture and Forestry \\ Savanorių 287, Kaunas, Lithuania \\ E-mail: agrolab@agrolab.lt \\ ${ }^{2}$ Elmininkai Experimental Station, Lithuanian Research Centre for Agriculture and Forestry \\ Elmininkai, Anykščiai distr., Lithuania
}

\begin{abstract}
In 2015-2016, research was carried out on a Haplic Luvisol ( $L V-h a)$ with predominant sandy loam and a $\mathrm{pH}_{\mathrm{KCl}}$ of 4.9-5.2 with a view to finding out how composts produced from sewage sludge, green waste and biogas production waste influenced potato tuber, spring oilseed rape seed and threshing residues yields as well as the concentrations of nitrogen $(\mathrm{N})$, phosphorus $(\mathrm{P})$, potassium $(\mathrm{K})$ and heavy metals in tubers, seeds and threshing residues. An experiment was conducted in the fields of Elmininkai Experimental Station (Anykščiai distr., Eastern Lithuania) of the Lithuanian Research Centre for Agriculture and Forestry. The composts were incorporated into the soil twice, in September in 2012 and in October in 2014. The mineral fertilisers used were ammonium nitrate, granular superphosphate and potassium chloride. Mineral fertilisers were applied in spring prior to sowing. Potato tuber yield in the treatments without mineral fertilisation was significantly increased by all types of composts applied in the experiment: biogas production waste compost - by $48.0 \%$, green waste $-43.5 \%$, cattle manure $-33.9 \%$ and sewage sludge $-27.5 \%$. However, these composts did not increase spring oilseed rape seed and threshing residues yields. Mineral fertilisers had a greater impact on them - the achieved seed yield increase was $40.4 \%$ higher. Chemical composition analyses of potato tubers, spring oilseed rape seeds and threshing residues showed that biogas production waste compost increased $\mathrm{N}$ concentration. In potato tubers $\mathrm{K}$ concentration was increased by all investigated composts, but most of all - by that of manure. In rape seeds, K concentration was increased by biogas production waste, sewage sludge and manure composts. In the yields of the investigated plants $\mathrm{P}$ concentrations were not affected by any of the composts applied. Compost influence on the variations of individual heavy metal $(\mathrm{Cu}, \mathrm{Zn}, \mathrm{Mn}, \mathrm{Pb}, \mathrm{Cd}$ and $\mathrm{Ni}$ ) concentrations in potato tubers, spring oilseed rape seeds and threshing residues was different.
\end{abstract}

Key words: composts, concentrations of chemical elements, potato, spring oilseed rape.

\section{Introduction}

The farmyard manure which was usually used in agriculture in order to restore the soil organic matter becomes more and more rare and expensive. However, municipal solid waste compost presents an interesting alternative; indeed, it constitutes an important organic mass for the formation of steady humus and contributes to the improvement of the fertility of soils (Pigozzo et al., 2006; Perez et al., 2007).

The accumulation of organic waste is thought to be reaching critical levels in almost all regions of the world (Troschinetz, Mihelcic, 2009). Nowadays, the organic waste utilisation involves technologies such as composting or anaerobic digestion that result in the

degradation and stabilisation of organic matter and mass and volume reduction (Basso et al., 2015). However, composting is at the moment the most widely used technology for the stabilisation of organic wastes due to the complexity and economic investment that anaerobic digestion requires (Cadena et al., 2009).

Using organic waste as a soil fertiliser offers a number of advantages over other management alternatives, because it reduces the use of other fertilisers and eliminates the necessity of its subsequent treatment or disposal (Hargreaves et al., 2008). Sewage sludge and farmyard manure are the most common organic wastes applied either raw or composted (i.e. humification of

Please use the following format when citing the article:

Staugaitis G., Narutytė I. , Arbačauskas J., Vaišvila Z., Rainys K., Mažeika R., Masevičienė A., Žičkienė L., Šumskis D., Gvildienė K. 2017. The influence of composts on potato tuber, spring oilseed rape seed and threshing residue yields and concentrations of chemical elements in them. Zemdirbyste-Agriculture, 104 (4): 329-336 DOI 10.13080/z-a.2017.104.042 
the organic matter under controlled conditions). The application of organic waste composts (i.e. sludge, biogas production or green waste) to land, especially agricultural crops, represents a significant input of nutrients (i.e. N, P and $\mathrm{K}$ ), but also of heavy metals ( $\mathrm{Zn}, \mathrm{Mn}, \mathrm{Cu}, \mathrm{Ni}, \mathrm{Cd}$ and $\mathrm{Cr}$ ), some of them being toxic like cadmium or lead (Song, Greenway, 2004; Lehtomaki, Bjornsson, 2006; Madrid et al., 2007).

Sewage sludge compost additions to agricultural land with background concentrations of heavy metals increase the soil content and the availability of heavy metals for transfer into crop plants. The total metal concentration in compost is important in controlling the crop uptake of labile elements, like $\mathrm{Zn}, \mathrm{Pb}$ and $\mathrm{Cu}$, which increases with increasing total content of these elements in compost (Smith, 2009; Lakhdar et al., 2010). The lowest metal materials, which include green waste compost, are likely to have inherently lower metal availabilities overall, at equivalent metal loading rates to soil, compared to composted residuals with larger metal contents (Zennaro et al., 2005).

Zheljazkov and Warman (2004) pointed out that municipal waste compost containing relatively large amounts of metals may be used as soil amendment on agricultural crops without the risk of phytotoxicity, or the risk of increasing crop tissue concentrations of $\mathrm{Cu}, \mathrm{Pb}$ and $\mathrm{Zn}$ above the normal range. However, the repeated application of compost can generate the accumulation of heavy metals in soils. Therefore, long-term effects of compost application on metal availability and effects on crops need to be considered (Kidd et al., 2007).

The aim of our research was to establish chemical composition of composts produced from cattle manure, sewage sludge, green waste and biogas production waste, and to ascertain how the composts influenced potato tuber and spring oilseed rape seed and threshing residues yields and the concentrations of nitrogen $(\mathrm{N})$, phosphorus $(\mathrm{P})$, potassium $(\mathrm{K})$ and heavy metals in them.

\section{Materials and methods}

Site description. The field experiment was conducted in 2012-2016 in the fields of Elmininkai Experimental Station (Anykščiai distr., Eastern Lithuania, $55^{\circ} 55^{\prime} 58.30^{\prime \prime} \mathrm{N}, 25^{\circ} 16^{\prime} 67.79^{\prime \prime}$ E) of the Lithuanian Research Centre for Agriculture and Forestry.

Soil. The experiment was conducted on a Haplic Luvisol (LV-ha) (WRB, 2014) with a texture of sandy loam with sandy clay loam in deeper layers, soil $\mathrm{pH}_{\mathrm{KCl}}$ - 4.9-5.2, organic carbon content $-1.04-1.57 \%$, content of plant available phosphorus $\left(\mathrm{P}_{2} \mathrm{O}_{5}\right)-193-237 \mathrm{mg} \mathrm{kg}^{-1}$ and potassium $\left(\mathrm{K}_{2} \mathrm{O}\right)-137-192 \mathrm{mg} \mathrm{kg}$. Heavy metal concentrations were as follows: cadmium $(\mathrm{Cd})-0.057-$ $0.096 \mathrm{mg} \mathrm{kg}^{-1}$, lead $(\mathrm{Pb})-6.87-8.90 \mathrm{mg} \mathrm{kg}^{-1}$, nickel $(\mathrm{Ni})$ - 9.67-13.1 mg kg-1, copper $(\mathrm{Cu})-3.93-6.43 \mathrm{mg} \mathrm{kg}^{-1}$, zinc $(\mathrm{Zn})-22.0-30 \mathrm{mg} \mathrm{kg}^{-1}$ and manganese $(\mathrm{Mn})-46$ $73 \mathrm{mg} \mathrm{kg}^{-1}$.

Experimental design. The field crop rotation established in 2012 included winter wheat $\rightarrow$ spring barley $\rightarrow$ potatoes $\rightarrow$ spring oilseed rape. During the first and third year of the experiment different composts were applied as fertilisers before sowing/planting according to the following scheme: 1) without fertilisers, 2) cattle manure compost, 3) green waste compost, 4) biogas production waste compost, 5) sewage sludge compost, 6) mineral fertilisation $\left(\mathrm{N}_{90} \mathrm{P}_{60} \mathrm{~K}_{90}\right)$, 7) cattle manure compost + mineral fertiliser, 8) green waste compost + mineral fertiliser, 9) biogas production waste compost
+ mineral fertiliser and 10) sewage sludge compost + mineral fertiliser.

Four replications of each treatment were used; the total size of the experimental plot was $72 \mathrm{~m}^{2}(12 \times$ $6 \mathrm{~m})$, harvested area $-22 \mathrm{~m}^{2}(10 \times 2.2 \mathrm{~m})$.

Description of the composts used: cattle manure compost - compost of animal solid manure with straw; green waste compost - urban green waste compost produced from cut grass, tree leaves and a small portion of shredded branches; biogas production waste compost biogas residue compost produced from processing spent grain under anaerobic conditions; sewage sludge compost - sewage sludge (from Vilnius municipality, Lithuania) mixed with straw ( $15 \%$ by volume). The composts were incorporated into the soil twice, in September in 2012 and in October in 2014. Together with the composts of all investigated types we incorporated $170 \mathrm{~kg} \mathrm{ha}^{-1}$ of nitrogen (N) into soil, therefore, different amounts of composts were applied: $16.1 \mathrm{t} \mathrm{ha}^{-1}$ of sewage sludge, $23.0 \mathrm{t} \mathrm{ha}^{-1}$ of biogas production waste, $31.2 \mathrm{t} \mathrm{ha}^{-1}$ of green waste compost and $45.3 \mathrm{t} \mathrm{ha}^{-1}$ of manure compost.

The influence of the composts used on the yield and quality of the first two plants in the crop rotation (winter wheat and spring barley) was described in this journal previously (Staugaitis et al., 2016), and for the purposes of this article, we discuss their influence on potatoes and the spring oilseed rape grown after the potato crop following the second compost incorporation.

After the incorporation of fertilisers in the experiment, potatoes cultivar 'Vineta' and after that spring oilseed rape cultivar 'Mosaik' were grown. The rates of composts were calculated based on the maximum permitted $\mathrm{N}$ rate of $170 \mathrm{~kg} \mathrm{ha}^{-1}$, as it was indicated in the EC Directive 91/676/EEC. Chemical composition of the composts and the amounts of nutrients and heavy metals incorporated together with them during the experiments are presented in Tables 1 and 2 .

The mineral fertilisers used were ammonium nitrate, granular superphosphate and potassium chloride. Mineral fertilisers were applied in spring prior to sowing. Potato tubers were planted on the $12^{\text {th }}$ of May in 2015 and harvested at senescence stage (BBCH 97). Spring oilseed rape was sown on the $3^{\text {rd }}$ of May in 2016 and harvested at maturity stage (BBCH 89$)$.

Herbicide Titus ${ }^{\circledR} 25$ DF (a.i. rimsulfuron $250 \mathrm{~g} \mathrm{~kg}^{-1}$, rate $0.05 \mathrm{~kg} \mathrm{ha}^{-1}$ ), fungicides Infinito ${ }^{\circledR} \mathrm{SC}$ 687.5 (a.i. propamocarb hydrochloride $625 \mathrm{~g} \mathrm{l}^{-1}$, and fluopicolide $62.5 \mathrm{~g} \mathrm{l}^{-1}$, rate $1.4-1.61 \mathrm{ha}^{-1}$ ), Ranman ${ }^{\circledR}$ TOP (a.i. cyazofamid $160 \mathrm{~g} \mathrm{l}^{-1}$, rate $0.5 \mathrm{l} \mathrm{ha}^{-1}$ ) and insecticide Actara $25 \mathrm{WG}$ (a.i. thiamethoxam $250 \mathrm{~g} \mathrm{~kg}^{-1}$, rate $\left.80 \mathrm{~g} \mathrm{ha}^{-1}\right)$ were applied on potatoes. Herbicide Sultan ${ }^{\circledR} 50$ $\mathrm{SC}$ (a.i. metazachlor $500 \mathrm{~g} \mathrm{l}^{-1}$, rate $1.51 \mathrm{ha}^{-1}$ ) as well as insecticides Fastac 50 (a.i. alpha-cypermethrin $50 \mathrm{~g} \mathrm{l}^{-1}$, rate $0.21 \mathrm{ha}^{-1}$ ), Proteus ${ }^{\circledR} 110 \mathrm{OD}$ (a.i. thiacloprid $100 \mathrm{~g} \mathrm{l}^{-1}$ and deltamethrin $10 \mathrm{~g} \mathrm{l}^{-1}$, rate $0.75 \mathrm{l} \mathrm{ha}^{-1}$ ), Karate Zeon $5 \mathrm{CS}$ (a.i. lambda-cyhalothrin $50 \mathrm{~g}^{-1}$, rate $0.151 \mathrm{ha}^{-1}$ ), Avaunt $^{\circledR}$ (a.i. indoxacarb $150 \mathrm{~g} \mathrm{l}^{-1}$, rate $170 \mathrm{ml} \mathrm{ha}^{-1}$ ) and Biscaya $^{\circledR}$ OD (a.i. thiacloprid $240 \mathrm{~g} \mathrm{l}^{-1}$, rate $0.3 \mathrm{l} \mathrm{ha}^{-1}$ ) were applied on spring oilseed rape.

Soil, compost and plant sampling and analytical methods. Soil samples for determination of agrochemical parameters were collected from $0-20 \mathrm{~cm}$ soil layer of the first and third replication plots before incorporation of fertilisers. Compost samples for quality analyses were taken in two replications, each of which consisted of 20 discrete subsamples. During harvesting potato tubers, spring oilseed rape seed and threshing residues yields collected from each experimental plot was weighed 
separately and the same day spring oilseed rape seeds and threshing residues moisture content was determined. Tuber, seed and threshing residues samples for determination of chemical composition were collected from the first and third replications of treatments Nos. $1-5$, for a large number of samples. The tuber yield was expressed in fresh matter, seeds - in 9\% moisture content and the threshing residues yield - in dry matter content.

Soil $\mathrm{pH}_{\mathrm{KCl}}$ was determined in $1 \mathrm{~N} \mathrm{KCl}$ extract using potentiometric method, plant available phosphorus and potassium content - according to Egner-RiehmDomingo (A-L) method, organic carbon content by dry combustion method. Dry matter in composts was determined in accordance with the standard EN 13040:2007, $\mathrm{pH}_{\mathrm{H}_{2} \mathrm{O}}$ - according to EN 13037:1999, organic matter - according to EN 13039:1999, total nitrogen - according to EN 13342:2000 using a nitrogen distiller, total phosphorus - according to EN 13650:2001 and EN ISO 11885:2009 using a flame photometer, and total potassium - according to EN 13650:2001 and ISO 9964-3:1993. Heavy metals in soil were determined in aqua regia, according to the standards ISO 11466:1995, ISO 11047:1998 and ISO 22036:2008, in composts - EN 13650:2001, EN ISO 15586:2003 and EN ISO 11885:2009.

To determine the chemical composition of potato tubers, spring oilseed rape seeds and threshing residues the following procedure was used: ground plant mass was combusted in a muffle furnace at $550^{\circ} \mathrm{C}$ for 12 hours. Nitrogen concentration was determined using Kjeldahl method, potassium - by flame photometer.
Phosphorus and heavy metals were analysed according to the standard EN 15621:2012.

Weather conditions. Meteorological conditions during the experimental period were assessed according to the data from Elmininkai Meteorological Station. To describe natural irrigation conditions during plant vegetation periods Selianinov's hydrothermal coefficient (HTC) was used, calculated according to the formula: $\mathrm{HTC}=\mathrm{H} /(0.1 \times \Sigma \mathrm{T})$, where $\mathrm{H}$ represents precipitation during the analysed period $(\mathrm{mm})$, and $\Sigma \mathrm{T}$ stands for the sum of average daily temperatures higher than $10^{\circ} \mathrm{C}$ during the same period decreased 10 times (compared to evaporation rate - defines evaporation conditions). Vegetation periods according to HTC are divided into: HTC $>1.6-$ irrigation is excessive, HTC $=1.0 \ldots 1.5$ - optimal irrigation, HTC $=0.9 \ldots 0.8$ - weak drought, $\mathrm{HTC}=0.7 \ldots 0.6-$ moderate drought (arid), $\mathrm{HTC}=0.5$ ... 0.4 - heavy drought, HTC $<0.4$ - very heavy drought (Dirsè, Taparauskiené, 2010)

In 2015 during the plant vegetation period (MaySeptember), the sum of active temperatures was $2457.0^{\circ} \mathrm{C}$, rainfall amounted to $173.1 \mathrm{~mm}$. According to the HTC data presented in Figure, good moisture supply in May 2015 favoured potato tubers germination. In June, very heavy drought occurred $(\mathrm{HTC}=0.11)$, thus the potato growth was poor. July and August was characterised by a weak and very heavy drought $(\mathrm{HTC}=0.77$ and 0.23$)$, respectively. The first ten-day period of September was excessive in rainfall, the second and third ten day periods were close to optimal, consequently, these summer months were unfavourable for potato growth and tuber development.

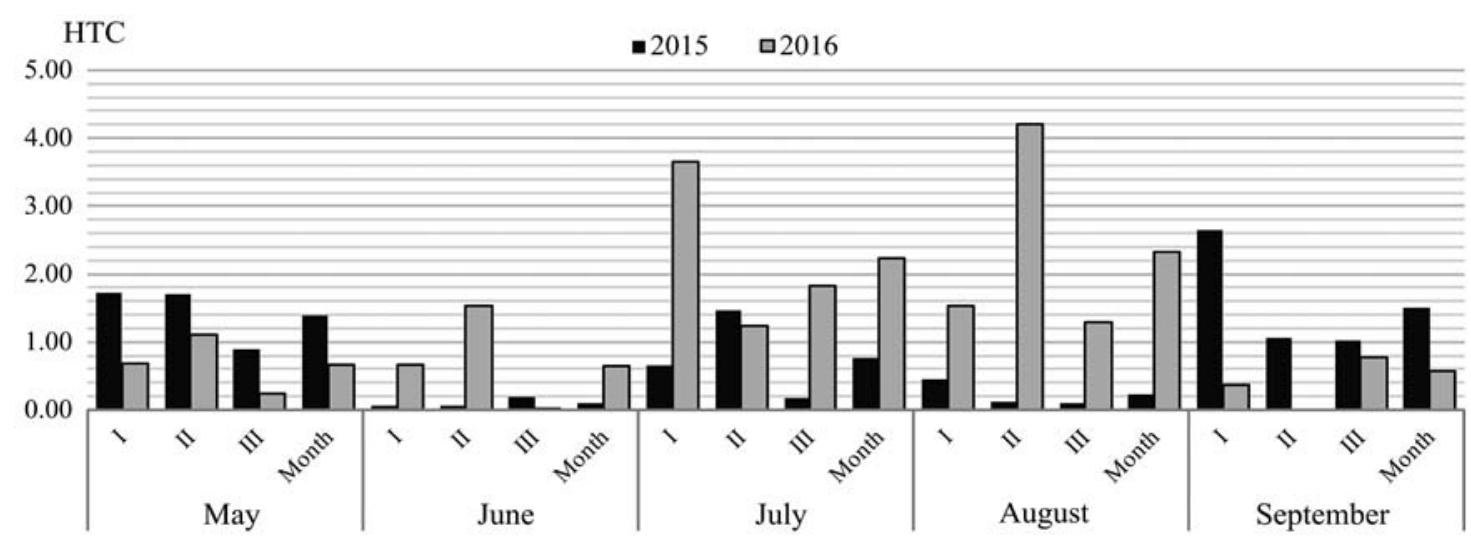

Figure. Hydrothermal coefficient (HTC) during plant vegetation period (Elmininkai Meteorological Station, 2015-2016)

In the beginning of May 2016, a moderate drought occurred after spring oilseed rape sowing; however, during the second ten-day period of May the weather was close to optimal irrigation and the third period was a very heavy drought, thus spring oilseed rape tillering was poor. In June, a moderate drought occurred $(\mathrm{HTC}=0.64)$; however, the rest of the spring oilseed rape growth period was abundant in rainfall. During the period from the beginning of May to the end of September, when the spring oilseed rape was harvested, the sum of active temperatures amounted to $2582.6^{\circ} \mathrm{C}$ and the rainfall was $334.9 \mathrm{~mm}$. Therefore, during July-August period the weather was favourable for spring oilseed rape growth.

Statistical analysis. Potato tuber and spring oilseed rape yield data were processed using the analysis of variance $(A N O V A)$. Statistical significance of the experimental data was assessed using Duncan's test; significant differences were established between the data lettered $\mathrm{a}, \mathrm{b}, \mathrm{c}, \mathrm{d}$, e and $\mathrm{f}$ at $5 \%$ probability level $(P \leq 0.05)$ (Tarakanovas, Raudonius, 2003). Compost and yield chemical composition data were presented as arithmetical means with standard deviations using software MS Excel 2007.

\section{Results and discussion}

Chemical composition of composts of different origin. Composts used in the experiment varied in their quality (Table 1). Biogas production waste compost had the highest nitrogen and phosphorus content, the content of the same materials in manure compost was somewhat lower, however, it had a lot of potassium, the content of which was approximately 7 times as high as that in green waste or sewage sludge composts and almost 3 times as high as that in biogas production waste compost. Biogas production waste and cattle manure composts had high 
Table 1. Chemical composition of composts used in the experiment

\begin{tabular}{|c|c|c|c|c|}
\hline Indicators & $\begin{array}{l}\text { Cattle manure } \\
\text { compost }\end{array}$ & $\begin{array}{l}\text { Green waste } \\
\text { compost }\end{array}$ & $\begin{array}{l}\text { Biogas production waste } \\
\text { compost }\end{array}$ & $\begin{array}{c}\text { Sewage sludge } \\
\text { compost }\end{array}$ \\
\hline Dry matter $\%$ & $14.0 \pm 2.1^{*}$ & $56.4 \pm 1.2$ & $20.1 \pm 5.3$ & $51.0 \pm 0.7$ \\
\hline $\mathrm{pH}_{\mathrm{H}_{2} \mathrm{O}}$ & $8.5 \pm 0.3$ & $7.6 \pm 0.6$ & $7.8 \pm 0.2$ & $7.0 \pm 1.0$ \\
\hline \multicolumn{5}{|c|}{ of dry matter } \\
\hline Total nitrogen $(\mathrm{N}) \%$ & $2.7 \pm 0.1$ & $1.0 \pm 0.3$ & $3.7 \pm 1.0$ & $2.1 \pm 0.6$ \\
\hline Total phosphorus (P) \% & $1.0 \pm 0.1$ & $0.2 \pm 0.0$ & $1.7 \pm 0.8$ & $1.0 \pm 0.3$ \\
\hline Total potassium (K) \% & $2.8 \pm 0.6$ & $0.4 \pm 0.0$ & $1.0 \pm 0.5$ & $0.4 \pm 0.0$ \\
\hline Organic matter $\%$ & $71.4 \pm 5.7$ & $19.6 \pm 2.2$ & $80.1 \pm 1.7$ & $34.9 \pm 4.8$ \\
\hline Cadmium (Cd) $\mathrm{mg} \mathrm{kg}^{-1}$ & $0.2 \pm 0.0$ & $0.2 \pm 0.0$ & $0.3 \pm 0.0$ & $1.6 \pm 0.2$ \\
\hline Nickel (Ni) $\mathrm{mg} \mathrm{kg}^{-1}$ & $3.8 \pm 0.5$ & $5.3 \pm 0.3$ & $9.6 \pm 0.3$ & $23.6 \pm 3.9$ \\
\hline Lead $(\mathrm{Pb}) \mathrm{mg} \mathrm{kg}^{-1}$ & $4.2 \pm 0.8$ & $11.7 \pm 5.4$ & $2.6 \pm 0.1$ & $34.2 \pm 7.7$ \\
\hline Zinc $(\mathrm{Zn}) \mathrm{mg} \mathrm{kg}^{-1}$ & $86.0 \pm 35.4$ & $115.0 \pm 2.8$ & $292.5 \pm 36.1$ & $477.0 \pm 240.4$ \\
\hline Copper $(\mathrm{Cu}) \mathrm{mg} \mathrm{kg}^{-1}$ & $22.1 \pm 0.5$ & $19.8 \pm 0.8$ & $49.2 \pm 14.1$ & $125.5 \pm 0.7$ \\
\hline Manganese (Mn) $\mathrm{mg} \mathrm{kg}^{-1}$ & $289.5 \pm 54.4$ & $207.0 \pm 42.4$ & $299.0 \pm 14.1$ & $269.0 \pm 72.1$ \\
\hline
\end{tabular}

* - means \pm standard deviation (SD)

contents of organic matter, amounting to $80.1 \%$ and $71.4 \%$, respectively; however, they were low in dry matter $-20.1 \%$ and $14.0 \%$, respectively. The lowest contents of nitrogen, phosphorus and organic matter were found in green waste compost.

Cattle manure and green waste composts had the lowest contents of heavy metals (Table 1). In comparison with them, $\mathrm{Cd}, \mathrm{Ni}, \mathrm{Zn}$ and $\mathrm{Cu}$ contents in biogas production waste compost was 1.5 and 3.4 times as high. The contents of heavy metals in sewage sludge compost were significantly higher compared with other composts analysed, especially those of $\mathrm{Cd}, \mathrm{Ni}, \mathrm{Pb}, \mathrm{Zn}$ and $\mathrm{Cu}$.

Together with the composts analysed different amounts of the main macroelements and heavy metals entered soil (Table 2). A total of $66 \mathrm{~kg} \mathrm{ha}^{-1}$ of phosphorus $\left(\mathrm{P}_{2} \mathrm{O}_{5}\right)$ entered soil with green waste compost, whereas, its amounts entered with other types of compost were 2.2-2.7 times as high. Fertilisation with manure compost resulted in very high amounts of potassium $\left(\mathrm{K}_{2} \mathrm{O}\right)$ - actually $214 \mathrm{~kg} \mathrm{ha}^{-1}$, whereas $43-89 \mathrm{~kg} \mathrm{ha}^{-1}$ were brought into soil with other composts. Sewage sludge incorporation was particularly distinguished for bringing in huge amounts of heavy metals and their quantities, as compared to other types of composts, differed from a few to several tens of times.

Influence of composts on yield of potatoes and spring oilseed rape. The influence exerted by different composts on potato tuber, spring oilseed rape seed and threshing residue yields varied (Table 3). All composts used in the experiment significantly increased potato tuber yield in the plots fertilised only with composts without the addition of mineral fertilisers compared to
Table 2. Amounts of organic matter $\left(\mathrm{t} \mathrm{ha}^{-1}\right)$, phosphorus, potassium $\left(\mathrm{kg} \mathrm{ha}^{-1}\right)$ and heavy metals $\left(\mathrm{g} \mathrm{ha}^{-1}\right)$ incorporated in soil together with composts

\begin{tabular}{lcccc}
\hline \multirow{2}{*}{ Indicators } & \multicolumn{4}{c}{ Composts } \\
\cline { 2 - 5 } & $\begin{array}{c}\text { cattle } \\
\text { manure }\end{array}$ & $\begin{array}{c}\text { green } \\
\text { waste }\end{array}$ & $\begin{array}{c}\text { biogas } \\
\text { production } \\
\text { waste }\end{array}$ & $\begin{array}{c}\text { sewage } \\
\text { sludge }\end{array}$ \\
\hline Organic matter & 4.5 & 3.4 & 3.7 & 2.9 \\
$\mathrm{P}_{2} \mathrm{O}_{5}$ & 142 & 66 & 175 & 181 \\
$\mathrm{~K}_{2} \mathrm{O}$ & 214 & 89 & 54 & 43 \\
$\mathrm{Cd}$ & 1.0 & 2.8 & 1.3 & 13.1 \\
$\mathrm{Ni}$ & 24 & 93 & 44 & 194 \\
$\mathrm{~Pb}$ & 27 & 206 & 12 & 280 \\
$\mathrm{Zn}$ & 545 & 2024 & 1352 & 3917 \\
$\mathrm{Cu}$ & 140 & 348 & 227 & 1030 \\
$\mathrm{Mn}$ & 1836 & 3643 & 1382 & 2209 \\
\hline
\end{tabular}

unfertilised plots: biogas production waste compost - by $48.0 \%$, green waste $-43.5 \%$, farmyard manure $-33.9 \%$ and sewage sludge $-27.5 \%$. Compared to the unfertilised plots mineral fertiliser significantly increased tuber yield by $47.0 \%$. However, only farmyard manure compost used with mineral fertilisers increased tuber yield and a yield increase obtained was $32.0 \%$ higher compared with that fertilised only with mineral fertilisers. A higher tuber yield was determined by higher levels of potassium incorporated together with manure compost, which actually amounted to $214 \mathrm{~kg} \mathrm{ha}^{-1}$, whereas its incorporation with other composts resulted in 43-89 $\mathrm{kg} \mathrm{ha}^{-1}$. Balemi (2012) found that manure used in combination with mineral fertiliser increased potato tuber yield more compared to the application of this fertiliser alone.

Table 3. Potato tuber and spring oilseed rape yield $\left(\mathrm{t} \mathrm{ha}^{-1}\right)$ as effected by different kinds of composts

\begin{tabular}{|c|c|c|c|}
\hline \multirow{2}{*}{ Fertilisation } & \multirow{2}{*}{$\begin{array}{c}\text { Potato tuber } \\
\text { yield }\end{array}$} & \multicolumn{2}{|c|}{ Spring oilseed rape yield } \\
\hline & & seeds & threshing residues \\
\hline Without fertilisers & $21.48 \mathrm{a}$ & $1.71 \mathrm{a}$ & $1.26 \mathrm{a}$ \\
\hline Cattle manure compost & $28.77 \mathrm{bcd}$ & 1.99 abcd & $1.70 \mathrm{bcd}$ \\
\hline Green waste compost & 30.82 bcde & $1.90 \mathrm{ab}$ & $1.61 \mathrm{ab}$ \\
\hline Biogas production waste compost & 31.80 bcdef & $1.93 \mathrm{abc}$ & $1.35 \mathrm{ab}$ \\
\hline Sewage sludge compost & $27.38 \mathrm{bc}$ & $2.01 \mathrm{abcd}$ & $1.66 \mathrm{~b}$ \\
\hline Mineral fertiliser & 31.57 bcde & $2.40 \mathrm{def}$ & $1.65 \mathrm{~b}$ \\
\hline Cattle manure compost + mineral fertiliser & $41.66 \mathrm{~h}$ & $2.46 \mathrm{f}$ & $2.08 \mathrm{~d}$ \\
\hline Green waste compost + mineral fertiliser & 35.31 ef & 2.14 bcdef & $1.44 \mathrm{ab}$ \\
\hline Biogas production waste compost + mineral fertiliser & 33.28 def & 2.23 bcdef & $1.68 \mathrm{bcd}$ \\
\hline Sewage sludge compost + mineral fertiliser & $32.88 \mathrm{cdef}$ & 2.31 cdef & $1.34 \mathrm{ab}$ \\
\hline
\end{tabular}


Fertilisation of spring oilseed rape with mineral fertilisers resulted in a significant increase in seed yield by $40.4 \%$ and that of threshing residues - by $31.0 \%$ compared to unfertilised crops. The application of composts used with mineral fertilisers did not significantly increase oilseed rape seed yield, only farmyard manure compost increased threshing residues yield by $26.1 \%$. The yield of spring oilseed rape fertilised with composts without any addition of mineral fertiliser did not increase either.

Both fertilisation with mineral fertilisers and composts had influence on potato tuber yield. Meanwhile, only mineral fertiliser had influence on spring oilseed rape seed yield. A similar trend was found by Rathke and Schuster (2001); however, Sistani et al. (2017) indicated that organic fertilisers increased yields significantly compared to mineral fertilisers.
Chemical composition of plant yield. Total nitrogen, phosphorus and potassium concentrations in potato tubers are presented in Table 4 and those in spring oilseed rape seeds and threshing residues are given in Table 5. The influence of composts used without mineral fertilisers was investigated, i.e. plots of treatment 1-5.

The nitrogen concentration in potato tubers varied within a small range of $1.24-1.35 \%$, the concentration determined was higher compared to those indicated by other researchers - 1.19-1.21\% (Sądej, Namiotko, 2011). It was higher in the potato tubers fertilised with biogas production waste compost - a nitrogen increase accounted for $0.11 \%$. This suggests a presumption that following the fertilisation with this compost in autumn, the amount of nitrogen in soil assimilated by plants was higher while growing potatoes. The composts applied had no effect

Table 4. Nitrogen (N), phosphorus $(\mathrm{P})$ and potassium $(\mathrm{K})$ concentrations in potato tubers

\begin{tabular}{lcc}
\hline \multicolumn{1}{c}{ Fertilisation } & $\mathrm{N}$ & $\mathrm{P}$ \\
\cline { 2 - 3 } & & \% of dry matter \pm SD \\
\hline Without fertilisers & $1.24 \pm 0.25$ & $0.20 \pm 0.01$ \\
Cattle manure compost & $1.29 \pm 0.06$ & $0.21 \pm 0.03$ \\
Green waste compost & $1.24 \pm 0.06$ & $0.18 \pm 0.02$ \\
Biogas production waste compost & $1.35 \pm 0.01$ & $0.23 \pm 0.02$ \\
Sewage sludge compost & $1.24 \pm 0.06$ & $0.21 \pm 0.01$ \\
\hline
\end{tabular}

Table 5. Nitrogen $(\mathrm{N})$, phosphorus $(\mathrm{P})$ and potassium $(\mathrm{K})$ concentrations in spring oilseed rape seeds and threshing residues

\begin{tabular}{lccrrrr}
\hline \multirow{2}{*}{\multicolumn{1}{c}{ Fertilisation }} & $\mathrm{N}$ & $\mathrm{P}$ & $\mathrm{K}$ & $\mathrm{N}$ & $\mathrm{P}$ \\
\cline { 2 - 6 } & \multicolumn{4}{c}{ \% of dry matter \pm SD } \\
\cline { 2 - 6 } & & \multicolumn{2}{c}{ seeds } & \multicolumn{2}{c}{ threshing residues } \\
\hline Without fertilisers & $3.87 \pm 0.03$ & $0.77 \pm 0.00$ & $0.79 \pm 0.04$ & $0.82 \pm 0.01$ & $0.11 \pm 0.03$ & $1.38 \pm 0.18$ \\
Cattle manure compost & $3.88 \pm 0.03$ & $0.82 \pm 0.05$ & $0.87 \pm 0.00$ & $0.82 \pm 0.02$ & $0.12 \pm 0.01$ & $1.36 \pm 0.04$ \\
Green waste compost & $3.92 \pm 0.08$ & $0.79 \pm 0.02$ & $0.83 \pm 0.06$ & $0.83 \pm 0.01$ & $0.12 \pm 0.00$ & $1.47 \pm 0.08$ \\
Biogas production waste compost & $4.00 \pm 0.10$ & $0.82 \pm 0.00$ & $0.89 \pm 0.02$ & $0.94 \pm 0.14$ & $0.15 \pm 0.02$ & $1.53 \pm 0.01$ \\
Sewage sludge compost & $3.91 \pm 0.04$ & $0.76 \pm 0.01$ & $0.89 \pm 0.03$ & $0.82 \pm 0.03$ & $0.14 \pm 0.00$ & $1.46 \pm 0.33$ \\
\hline
\end{tabular}

on phosphorus content in potato tubers. Meanwhile, potassium concentration in tubers was increased by all composts studied but the highest concentration was achieved by using manure compost $-0.57 \%$. That was due to the fact that substantially higher potassium levels were incorporated into soil together with this compost.

The composts analysed in spring oilseed rape increased nitrogen concentration in seeds from $0.01 \%$ to $0.13 \%$ and in threshing residues - from $0.01 \%$ to $0.12 \%$, compared to the control plot. The highest concentration of nitrogen of $4.00 \%$ and $0.94 \%$ was achieved in rape seeds and threshing residues, respectively, as well as in potato tubers after fertilisation with biogas production waste compost. Phosphorus concentrations in spring oilseed rape seeds and threshing residues varied within the limits of accepted tolerances. The concentration of total potassium in spring oilseed rape threshing residues varied within the tolerance range as well; however, in seeds it was marginally increased by the application of manure, biogas production waste and sewage sludge composts. According to the data of other authors (Yasari et al., 2009), nitrogen concentrations (using no fertilisers) in spring oilseed rape seeds amounted to $3.39 \%$, phosphorus $-0.58 \%$ and potassium $-0.56 \%$.

Having evaluated the chemical composition analyses of two crops it was established that biogas production waste compost increased nitrogen concentration in plants. Potassium concentration in potato tubers was increased by all analysed composts but most of all it was increased by manure compost. Potassium concentration in spring oilseed rape seeds was increased by biogas production waste, sludge and manure composts. The composts used had no effect on phosphorus concentrations in the crops studied.
Content of heavy metals in grain and threshing residues. The influence of different composts on heavy metal content in potato tubers and spring oilseed rape seeds and threshing residues is presented in Tables 6 and 7.

Some heavy metals, including $\mathrm{Cu}, \mathrm{Zn}$ and $\mathrm{Mn}$ are required by plants as microelements. However, higher contents of even the most necessary microelements can have a toxic effect on plants; suppress plant development, photosynthesis and fermentation activity (Benavides et al., 2005).

Scientific literature indicates that copper $\mathrm{Cu}$ ) concentration in potato tubers range within 3.0 $6.6 \mathrm{mg} \mathrm{kg}^{-1}$, and that in spring oilseed rape seeds and threshing residues -5.2 and $2.0 \mathrm{mg} \mathrm{kg}^{-1}$, respectively (Kabata-Pendias, 2011; Jankowski et al., 2014). In our research, $\mathrm{Cu}$ concentration in potato tubers ranged within an interval of $5.68-8.84 \mathrm{mg} \mathrm{kg}^{-1}$, and that in spring oilseed rape seeds was $2.55-3.15 \mathrm{mg} \mathrm{kg}^{-1}$ and in threshing residues it was $3.62-5.41 \mathrm{mg} \mathrm{kg}^{-1}$. The analysed crops demonstrated a marginally higher $\mathrm{Cu}$ concentration (8.84 and $\left.7.94 \mathrm{mg} \mathrm{kg}^{-1}\right)$ after having fertilised them with sewage sludge and biogas production waste composts.

The experiment revealed that zinc $(\mathrm{Zn})$ concentration in potato tubers ranged within 11.61$14.35 \mathrm{mg} \mathrm{kg}^{-1}$ and that in spring oilseed rape seeds and threshing residues it was 26.20-28.95 and 4.58$5.59 \mathrm{mg} \mathrm{kg}^{-1}$, respectively. The variations achieved were within the limits of accepted tolerances; therefore, there was no regular influence of composts identified on $\mathrm{Zn}$ concentrations in the analysed potato tubers and spring oilseed rape seeds and threshing residues. The exception was rape threshing residues which demonstrated an increased $\mathrm{Zn}$ concentration after fertilisation with biogas 
Table 6. Concentrations of heavy metals in potato tubers as effected by the application of different kinds of composts

\begin{tabular}{|c|c|c|c|c|c|c|}
\hline \multirow{2}{*}{ Fertilisation } & $\mathrm{Cu}$ & $\mathrm{Zn}$ & $\mathrm{Mn}$ & $\mathrm{Pb}$ & $\mathrm{Cd}$ & $\mathrm{Ni}$ \\
\hline & \multicolumn{6}{|c|}{$\mathrm{mg} \mathrm{kg}^{-1}$ of dry matter $\pm \mathrm{SD}$} \\
\hline Without fertilisers & $5.68 \pm 0.50$ & $11.61 \pm 2.52$ & $3.25 \pm 0.02$ & $0.077 \pm 0.051$ & $0.078 \pm 0.022$ & $0.225 \pm 0.021$ \\
\hline Cattle manure compost & $6.06 \pm 0.11$ & $12.65 \pm 0.50$ & $3.26 \pm 0.28$ & $0.076 \pm 0.052$ & $0.076 \pm 0.001$ & $0.210 \pm 0.042$ \\
\hline Green waste compost & $7.38 \pm 1.03$ & $13.00 \pm 3.39$ & $3.64 \pm 1.00$ & $0.082 \pm 0.021$ & $0.089 \pm 0.025$ & $0.245 \pm 0.021$ \\
\hline Biogas production waste compost & $7.94 \pm 2.26$ & $12.10 \pm 2.40$ & $3.50 \pm 0.06$ & $0.077 \pm 0.011$ & $0.082 \pm 0.044$ & $0.285 \pm 0.148$ \\
\hline Sewage sludge compost & $8.84 \pm 1.93$ & $14.35 \pm 1.77$ & $3.28 \pm 0.26$ & $0.078 \pm 0.004$ & $0.080 \pm 0.008$ & $0.233 \pm 0.018$ \\
\hline
\end{tabular}

Table 7. Concentrations of heavy metals in spring oilseed rape seeds and threshing residues as affected by the application of different kinds of composts

\begin{tabular}{|c|c|c|c|c|c|c|}
\hline \multirow{2}{*}{ Fertilisation } & $\mathrm{Cu}$ & $\mathrm{Zn}$ & $\mathrm{Mn}$ & $\mathrm{Pb}$ & $\mathrm{Cd}$ & $\mathrm{Ni}$ \\
\hline & \multicolumn{6}{|c|}{$\mathrm{mg} \mathrm{kg}^{-1}$ of dry matter $\pm \mathrm{SD}$} \\
\hline \multicolumn{7}{|c|}{ Seeds } \\
\hline Without fertilisers & $2.55 \pm 0.20$ & $26.20 \pm 0.28$ & $40.50 \pm 19.8$ & $0.012 \pm 0.001$ & $0.034 \pm 0.004$ & $0.080 \pm 0.028$ \\
\hline Cattle manure compost & $2.68 \pm 0.39$ & $28.50 \pm 0.85$ & $40.35 \pm 1.20$ & $0.020 \pm 0.002$ & $0.036 \pm 0.006$ & $0.085 \pm 0.049$ \\
\hline Green waste compost & $2.55 \pm 0.20$ & $28.15 \pm 2.47$ & $40.50 \pm 2.40$ & $0.024 \pm 0.006$ & $0.036 \pm 0.002$ & $0.115 \pm 0.092$ \\
\hline Biogas production waste compost & $3.03 \pm 0.04$ & $28.50 \pm 0.85$ & $42.40 \pm 4.10$ & $0.020 \pm 0.006$ & $0.036 \pm 0.004$ & $0.080 \pm 0.042$ \\
\hline Sewage sludge compost & $3.15 \pm 0.19$ & $28.95 \pm 3.61$ & $45.85 \pm 9.12$ & $0.031 \pm 0.013$ & $0.034 \pm 0.001$ & $0.110 \pm 0.014$ \\
\hline \multicolumn{7}{|c|}{ Threshing residues } \\
\hline Without fertilisers & $3.62 \pm 0.35$ & $4.58 \pm 0.11$ & $9.36 \pm 0.62$ & $0.028 \pm 0.004$ & $0.150 \pm 0.057$ & $0.195 \pm 0.049$ \\
\hline Cattle manure compost & $3.99 \pm 0.47$ & $4.77 \pm 1.25$ & $9.58 \pm 4.99$ & $0.034 \pm 0.004$ & $0.150 \pm 0.028$ & $0.170 \pm 0.042$ \\
\hline Green waste compost & $3.99 \pm 1.16$ & $4.66 \pm 0.80$ & $10.66 \pm 5.01$ & $0.029 \pm 0.003$ & $0.180 \pm 0.028$ & $0.200 \pm 0.014$ \\
\hline Biogas production waste compost & $5.17 \pm 2.08$ & $5.59 \pm 0.32$ & $12.35 \pm 6.86$ & $0.030 \pm 0.006$ & $0.160 \pm 0.028$ & $0.230 \pm 0.085$ \\
\hline Sewage sludge compost & $5.41 \pm 0.36$ & $5.02 \pm 0.19$ & $9.22 \pm 4.50$ & $0.035 \pm 0.005$ & $0.170 \pm 0.028$ & $0.230 \pm 0.085$ \\
\hline
\end{tabular}

production waste and sewage sludge composts. Zinc concentrations determined in the primary and secondary plant produce during the experiment did not exceed the ones suggested by the majority of researchers, namely: in potato tubers $-5.1-35.0 \mathrm{mg} \mathrm{kg}^{-1}$, spring oilseed rape seeds $-55.4 \mathrm{mg} \mathrm{kg}^{-1}$ and in threshing residues -11.5 $\mathrm{mg} \mathrm{kg}^{-1}$ (Pollak, Favoino, 2004; Kabata-Pendias, 2011; Jankowski et al., 2014).

Manganese (Mn) is a nutrient found in plant tissue at concentrations ranging from 10 to $500 \mathrm{mg} \mathrm{kg}^{-1}$ or more. In most plants, it is deficient at less than $10 \mathrm{mg} \mathrm{kg}^{-1}$ and toxic when the concentration exceeds about $300 \mathrm{mg} \mathrm{kg}^{-1}$; potato is a plant with medium Mn needs (Sturgul, 2010). In our research, Mn concentration in potato tubers ranged within an interval of $3.25-3.64 \mathrm{mg} \mathrm{kg}^{-1}$. The composts applied did not increase Mn concentration in potato tubers; the concentration determined was lower compared to those indicated by other researchers - 4-15 mg kg-1 (KabataPendias, 2011). The optimal manganese concentration in the aboveground spring oilseed rape mass at different growth stages is $20-150 \mathrm{mg} \mathrm{kg}^{-1}$ (Bergman, 1986). The Mn concentrations in spring oilseed rape seeds and threshing residues during the experiment ranged within the limits of $40.35-45.85$ and $9.22-12.35 \mathrm{mg} \mathrm{kg}^{-1}$, respectively. Rape threshing residues demonstrated a higher Mn concentration after fertilisation with biogas production waste compost. During the experiment Mn concentration in spring oilseed rape seeds was marginally higher than that in threshing residues compared to the concentrations indicated by other researchers: $37.8-40.8 \mathrm{mg} \mathrm{kg}^{-1}$ in seeds and $10.2-20.9 \mathrm{mg} \mathrm{kg}^{-1}$ in threshing residues (Jankowski et al., 2014).

There is a group of metals called heavy metals, because they are detrimental and widespread in metallurgical and chemical industries. Such elements include $\mathrm{Cd}, \mathrm{Pb}$ and $\mathrm{Ni}$. Increased concentrations of these elements in plants are undesirable (Alkorta et al., 2004); and the maximum permissible concentrations (MPC) of $\mathrm{Cd}$ and $\mathrm{Pb}$ in potatoes (MPC in peeled potatoes applied) under European Community Regulations No. 1881/2006 and No. 629/2008 shall not exceed $0.10 \mathrm{mg} \mathrm{kg}^{-1}$.
The concentration of lead $(\mathrm{Pb})$ found in potato tubers was higher compared to spring oilseed rape. It varied in potato tubers within a range of $0.077-$ $0.082 \mathrm{mg} \mathrm{kg}^{-1}$; however, it did not exceed the maximum permissible concentration limit of $0.10 \mathrm{mg} \mathrm{kg}^{-1}$ (Table 6). Lead concentrations established by other researchers vary substantially within a range of $0.001-2.2 \mathrm{mg} \mathrm{kg}^{-1}$ (Pollak, Favoino, 2004). The concentrations of this heavy metal found in spring oilseed rape seeds and threshing residues amounted to $0.012-0.031$ and $0.028-0.035 \mathrm{mg}$ $\mathrm{kg}^{-1}$, respectively. All investigated composts increased the concentration of $\mathrm{Pb}$ in rape seeds, but most of all it was attributed to sewage sludge compost. In addition, sewage sludge compost increased $\mathrm{Pb}$ concentration in rape threshing residues as well. According to the data by other authors, $\mathrm{Pb}$ concentrations in rape seeds after the application of sewage sludge were higher and amounted to $3.33-4.31 \mathrm{mg} \mathrm{kg}^{-1}$ (Krzywy, Iżewska, 2007).

Even though direct uptake from soil into a potato tubers is only a minor contribution to tuber $\mathrm{Cd}$ content (Reid et al., 2003), they accumulate more Cd than grain (Singh et al., 2012). The analysis of 16 potato cultivars grown at non-contaminated agricultural sites in Turkey showed that $\mathrm{Cd}$ concentrations were in a range of $0.08-0.32 \mathrm{mg} \mathrm{kg}^{-1}$, with significant differences between varieties (Öztürk et al., 2011). Our studies show that the concentration of $\mathrm{Cd}$ in potato tubers was low compared to the data by other researchers and it varied within a range of 0.076-0.089 mg kg-1 (Table 7). Cadmium concentrations in spring oilseed rape seeds and threshing residues ranged within the limits of $0.034-0.036$ and $0.150-0.180 \mathrm{mg} \mathrm{kg} \mathrm{kg}^{-1}$, respectively. Regardless of the type of compost used, $\mathrm{Cd}$ concentrations in rape seeds and threshing residues were within the limits of accepted tolerances and lower compared to the concentrations found by other authors in seeds $\left(0.230 \mathrm{mg} \mathrm{kg}^{-1}\right)$ and threshing residues $\left(1.552 \mathrm{mg} \mathrm{kg}^{-1}\right)$, when rape had been fertilised with sewage sludge compost (Krzywy, Iżewska, 2007).

According to the data obtained by Pollak and Favoino (2004) and Kabata-Pendias (2011), the concentration of nickel $(\mathrm{Ni})$ in potato tubers amounted to $0.187-1.000 \mathrm{mg} \mathrm{kg}^{-1}$. The concentration of $\mathrm{Ni}$ in 
our experiment ranged within the limits of accepted tolerances $-0.210-0.285 \mathrm{mg} \mathrm{kg}^{-1}$ and did not exceed the concentrations identified by other researchers. Nickel concentrations in spring oilseed rape seeds and threshing residues varied within a range of $0.080-0.115$ and 0.170 $0.230 \mathrm{mg} \mathrm{kg}^{-1}$, respectively. A higher $\mathrm{Ni}$ concentration in rape seeds was achieved by fertilising with green waste compost and that in threshing residues - with biogas production waste and sewage sludge composts Nickel concentration increases were not significant compared to those reported by other researchers, when having applied sewage sludge compost the resulting $\mathrm{Ni}$ concentration in rape seeds amounted to 2.58-2.86 and that in threshing residues was $1.50-1.54 \mathrm{mg} \mathrm{kg}^{-1}$ (Krzywy, Iżewska, 2007).

\section{Conclusions}

1. Manure, green waste, biogas production waste and sewage sludge composts differ significantly in chemical composition. Biogas production waste compost had the highest nitrogen $(\mathrm{N})$ and phosphorus $(\mathrm{P})$ content, the content of the same materials in manure compost was somewhat lower. However, manure compost had a lot of potassium $(\mathrm{K})$, the content of which was approximately 7 times as high as that in green waste or sewage sludge composts and almost 3 times as high as that in biogas production waste compost. Manure and biogas production waste composts had high contents of organic matter, amounting to $71.4 \%$ and $80.1 \%$, respectively. The lowest contents of N, P and organic matter were found in green waste compost. Sewage sludge compost had substantially more heavy metals compared to other composts - cadmium $(\mathrm{Cd})$, nickel $(\mathrm{Ni})$, lead $(\mathrm{Pb})$, zinc $(\mathrm{Zn})$ and copper $(\mathrm{Cu})$ contents were high in particular.

2 . The composts used without mineral fertilisers significantly increased potato tuber yield compared to unfertilised plots as follows: biogas production waste compost - by $48.0 \%$, green waste $-43.5 \%$, farmyard manure $-33.9 \%$, and sewage sludge $-27.5 \%$. However, these composts did not increase spring oilseed rape seed and threshing residues yield.

3. Analyses of chemical composition of potato tubers, spring oilseed rape seeds and threshing residues showed that biogas production waste compost increased $\mathrm{N}$ concentration. $\mathrm{K}$ concentration in potato tubers was increased by all investigated composts, but most of all by manure compost. $\mathrm{K}$ concentration in rape seeds was increased by biogas production waste, sewage sludge and manure composts. The composts used had no influence on $\mathrm{P}$ concentrations in primary and secondary production of the plants analysed.

4. The influence of composts on the variations in the concentrations of certain heavy metals in potato tubers, spring oilseed rape seeds and threshing residues was different. Higher concentrations of $\mathrm{Cu}$ were determined having fertilised plants with sewage sludge and biogas production waste composts. All investigated composts increased $\mathrm{Pb}$ concentration in rape seeds, but most of all the increase was attributed to sewage sludge compost. Higher concentrations of $\mathrm{Ni}$ in rape seeds were achieved after green waste compost application, and those in threshing residues - having fertilised with biogas production waste and sewage sludge composts. There were no consistent patterns of the increase in $\mathrm{Mn}, \mathrm{Zn}$ and $\mathrm{Cd}$ concentrations in crop yields established.

Received 19042017 Accepted 02102017

\section{References}

1. Alkorta I., Hernández-Allica J., Becerril J. M. Amezaga I., Albizu I., Garbisu C. 2004. Recent findings on the phytoremediation of soils contaminated with environmentally toxic heavy metals and metalloids such as zinc, cadmium, lead, and arsenic. Reviews in Environmental Science and Biotechnology 3 (1): 71-90. https://doi.org/10.1023/B:RESB.0000040059.70899.3d

2. Balemi 1. 2012. Etfect of integrated use of cattle manure and inorganic fertilizers on tuber yield of potato in Ethiopia. Journal of Soil Science and Plant Nutrition, 12 (2): 257265. https://doi.org/10.4067/S0718-95162012000200005

3. Basso D., Weiss-Hortala E., Patuzzi F., Castello D., Baratieri M., Fiori L. 2015. Hydrothermal carbonization of off-specification compost: a byproduct of the organic municipal solid waste treatment. Bioresource Technology, 182: 217-224. https://doi.org/10.1016/j.biortech.2015.01.118

4. Benavides M. P., Gallego S. M., Tomaro M. L. 2005. Cadmium toxicity in nlants. Plant Physiolngy, 17 (1): 21-34. https://doi.org/10.1590/S1677-0420200500010000́3

5. Bergmann W. 1986. Nutritional dysfunction in crops. Formation, visual and analytical diagnosis. Jena, Germany, p. 166-178 (in German).

6. Cadena E., Colón J., Artola A., Sánchez A., Font X. 2009. Environmental impact of two aerobic composting technologies using life cycle assessment. The International Journal of Life Cycle Assessment, 14 (5): 401-410. https://doi.org/10.1007/s11367-009-0107-3

7. Dirsè A., Taparauskienè L. 2010. Humidity fluctuations in plant vegetation periods and a comparison of its assessment methods. Zemės ūkio mokslai, 17 (1-2): 9-17 (in Lithuanian).

8. Hargreaves J. C., Adl M. S., Warman P. R. 2008. A review of the use of composted municipal solid waste in agriculture. Agriculture, Fcosystems and Fnvironment, 123 (1-3): 1-14. https://doi.org/10.1016/j.agee.2007.07.004

9. Jankowski K., Kijewski L., Skwierawska M., Krzebietke S., Mackiewicz-Walec E. 2014. Effect of sulfur fertilization on the concentrations of copper, zinc and manganese in the roots, straw and oil cake of rapeseed (Brassica napus L. ssp. oleifera Met7g). Journal of Elementologv. 19 (2): 433-446. https://doi.org/10.5601/jelem.2013.18.4.552

10. Kabata-Pendias A. 2011. Trace elements in soils and plants ( $4^{\text {th }}$ ed.). London, England.

11. Kidd P. S., Dominguez-Rodriguez M. J., Diez J., Monterroso C. 2007. Bioavailability and plant accumulation of heavy metals and phosphorus in agricultural soils amended by long-term anplication of sewage sludge. Chemosphere, 66: 1458-1467. https://doi.org/10.1016/j.chemosphere.2006.09.007

12. Krzywy E., Iżewska A. 2007. Impact of mature and organic fertilizers on the quantity and content yield of heavy metals in spring rape. Polish Inurnal of Chemical Technology, 9 (3): 60-63. https://doi.org/10.2478/v10026-007-0055-2

13. Lakhdar A., Iannelli M. A., Debez A., Massacci A., Jedidi N., Abdelly C. 2010. Effect of municipal solid waste compost and sewage sludge use on wheat (Triticum aestivum): growth, heavy metal accumulation and antioxidant activity. Journal of the Science of Food and Agriculture, 90 (6): 965-971. https://doi.org/10.1002/jsfa.3904

14. Lehtomaki A., Bjornsson L. 2006. Two-stage anaerobic digestion of energy crops; methane production, nitrogen mineralisation and heavy metal mobilisation. Environmental Technologv. 27 (2): 209-218. https://doi.org/10.1080/09593332708618635

15. Madrid F., López R., Cabrera F. 2007. Metal accumulation in soil after application of municipal solid waste compost under intensive farming conditions. Agriculture, Ecosystems and Fnvirnmment 119(3): 249-256 https://doi.org/10.1016/j.agee.2006.07.006

16. Öztürk E., Atsan E., I. Polat 'T., Kara K. 2011. Variation in heavy metal concentrations of potato (Solanum tuberosum L.) cultivars. The Journal of Animal and Plant Sciences, 21 (2): 235-239.

17. Perez D. V., Alcantra S., Ribeiro C. C., Pereira R. E., Fontes G. C., Wasserman M. A., Venezuela T. C., Meneguelli N. A., Parradas C. A. A. 2007. Composted municipal waste effects on chemical properties of Brazilian soil. Rioresource Technolngy, 98 (3): 52.5-533. https://doi.org/10.1016/j.biortech.2006.02.025 
18. Pigozzo A. T. G., Lenzi E., Junior J. L., Scapin C., Da Costa A. C. S. 2006. Transition metal rates in latosol twice treated with sewage sludge. Brazilian Archives of Biologv and Technologv. 49 (3): 515-526. https://doi.org/10.1590/S1516-89132006000400020

19. Pollak M., Favoino E. 2004. Heavy metals and organic compounds from wastes used as organic fertilisers: final report for Technical office for agriculture $<$ http://ec.europa. eu/environment/waste/compost/pdf/hm finalreport.pdf $>$ [accessed 0901 2017].

20. Rathke G. W., Schuster C. 2001. Yield and quality of winter oilseed rape related to nitrogen supply. Developments in Plant and Soil Sciences, 92: 79-799. https://doi.org/10.1007/0-306-47624-X 388

21. Reid R. J., Dunbar K. R., McLaughlin M. J. 2003. Cadmium loading into potato tubers: the roles of the periderm, xylem and phloem. Plant, Cell and Environment, 26 (2): 201-206. https://doi.org/10.1046/j.1365-3040.2003.00945.x

22. Sądej W., Namiotko A. 2011. Nitrates(V) content in potato tubers cultivated under various fertilization systems. Ecological Chemistry and Engineering, 18 (8): 1123-1130.

23. Singh S., Zacharias M., Kalpana S., Mishra S. 2012. Heavy metals accumulation and distribution pattern in different vegetable crops. Journal of Environmental Chemistry and Ecotoxicology, 4 (4): 75-81. http://www.academicjournals. org/journal/JECE/article-full-text-pdf/C0595D62947

24. Sistani K. R., Simmons J. R., Warren J. G., Higgins S. 2017. Nitrogen source and application method impact on corn yield and nutrient uptake. Journal of Plant Nutrition. 40 (6): 878-889. https://doi.org/10.1080/01904167.2016.1262410

25. Smith S. R. 2009. A critical review of the bioavailability and impacts of heavy metals in municipal solid waste composts compared to sewage sludge. Environment International, 35 (1): 142-156. https://doi.org/10.1016/j.envint.2008.06.009

26. Song Q. J., Greenway G. M. 2004. A study of the elemental leachability and retention capability of compost. Journal of
Environmental Monitoring. 6 (1): 31-37.

https://doi.org/10.1039/b310840f

27. Staugaitis G., Narutytė I., Arbačauskas J., Vaišvila Z., Rainys K., Mažeika R., Masevičienė A., Žičkienė L., Šumskis D. 2016. The influence of composts on grain and straw yields of winter wheat and spring barley and concentrations of chemical elements in them. Zemdirbyste-Agriculture, 103 (4): 355-362. https://doi.org/10.13080/z-a.2016.103.045

28. Sturgul S. J. 2010 . Soil micronutrients: trom boron to zinc. Proceedings of the 2010 Wisconsin Crop Management Conference, vol. 49, p. 14-21.

29. Tarakanovas P., Raudonius S. 2003. Agronominių tyrimų duomenų staitistinè analizè taikant kompiuterines programas ANOVA, STAT, SPLIT-PLOT iš paketo SELEKCIJA ir IRRISTAT. Lithuanian University of Agriculture, 58 p. (in Lithuanian).

30. Troschinetz A. M., Mihelcic J. R. 2009. Sustainable recycling of municipal solid waste in developing countries. https://doi.org/10.1016/j.wasman.2008.04.016

31. WRB. 2014. World reference base for soil resources 2014. International soil classification system for naming soils and creating legends for soil maps. World Soil Resources Reports No. 106. FAO, Rome, 187-192 p.

32. Yasari E., Esmaeili M. P., Mozafari S., Alashi M. R. 2009. Enhancement of growth and nutrient uptake of rapeseed (Brassica napus L.) by applying mineral nutrient and biofertilizers. Pakistan Journal of Biological Sciences. 12 (2): 127-133. https://doi.org/10.3923/pjbs.2009.127.133

33. Zennaro M., Cristotori F., Formigoni D., Frignani F., Pavoni B. 2005. Heavy metal contamination in compost. A possible solution. Annali di Chimica (Rome), 95 (3-4): 247-256. https://doi.org/10.1002/adic.200590027

34. Zheljazkov V. D., Warman P. R. 2004. Phytoavailability and fractionation of copper, manganese, and zinc in soil following application of two composts to four crops. Environmental Pollution. 131 (2): 187-195. https://doi.org/10.1016/j.envpol.2004.02.007

ISSN 1392-3196 / e-ISSN 2335-8947

Zemdirbyste-Agriculture, vol. 104, No. 4 (2017), p. 329-336

DOI $10.13080 /$ z-a.2017.104.042

\title{
Kompostų įtaka bulvių gumbų ir vasarinių rapsų sèklụ bei kūlenų derliui ir cheminių elementų koncentracijai
}

\author{
G. Staugaitis ${ }^{1}$, I. Narutyté ${ }^{1}$, J. Arbačauskas ${ }^{1}$, Z. Vaišvila ${ }^{1}$, K. Rainys ${ }^{2}$, R. Mažeika ${ }^{1}$,
} A. Masevičiené ${ }^{1}$, L. Žičkiené ${ }^{1}$, D. Šumskis ${ }^{1}$, K. Gvildiené ${ }^{1}$

${ }^{1}$ Lietuvos agrarinių ir miškų mokslų centro Agrocheminių tyrimų laboratorija

${ }^{2}$ Lietuvos agrarinių ir miškų mokslų centro Elmininkų bandymų stotis

\section{Santrauka}

Siekiant išsiaiškinti, kokią ịtaką iš nuotekų dumblo žaliųjų ir biodujų gamybos atliekų pagaminti kompostai turi bulvių gumbų ir vasarinių rapsų sẻklų bei kūlenų derliui ir jame esančių azoto (N), fosforo (P), kalio (K) bei sunkiųjų metalų koncentracijoms, 2015-2016 m. giliai glejjiškame paprastajame išplautžemyje (IDp-g0), kuriame vyravo smèlingas priemolis, $\mathrm{pH}_{\mathrm{KCl}} 4,9-5,2$, buvo atlikti tyrimai. Lauko eksperimentai vykdyti Lietuvos agrarinių ir miškų mokslo centro Elmininkų bandymų stoties (Anykščių r., Rytų Lietuva) laukuose. Kompostai ị dirvožemị įterpti du kartus: 2012 m. rugsèji ir 2014 m. spalį. Iš mineralinių trąšų naudota amonio salietra, granuliuotas superfosfatas ir kalio chloridas. Bulvėms ir vasariniams rapsams mineralinès trą̌sos išbertos pavasarị prieš sodinimą ir sẻją. Tyrimų duomenimis, fone be mineralinių trąšų bulvių gumbų derlių esmingai didino visi eksperimente naudoti kompostai: biodujų gamybos atliekos $-48,0 \%$, žaliosios atliekos $-43,5 \%$, kraikinis mèšlas - 33,9 \%, nuotekų dumblas - 27,5\%. Tačiau šie kompostai nedidino vasarinių rapsų sẻklų ir kūlenų derliaus. Didesnès įtakos jiems turejjo mineralinès trąšos - gautas 40,4 \% didesnis sẻklų derliaus priedas. Bulvių gumbų ir vasarinių rapsų sẻklų bei kūlenų cheminès sudèties tyrimai parodè, kad biodujų gamybos atliekų kompostas didino N koncentraciją. Bulvių gumbuose K koncentraciją didino visi tirti kompostai, labiausiai - méšlo. Rapsų sėklose K koncentraciją didino biodujų gamybos atliekų, nuotekų dumblo ir mëšlo kompostai. Naudoti kompostai P koncentracijai tirtų augalų derliuje neturejjo įtakos. Kompostų įtaka kai kurių sunkiụjų metalų $(\mathrm{Cu}, \mathrm{Zn}, \mathrm{Mn}, \mathrm{Pb}, \mathrm{Cd}$ ir $\mathrm{Ni})$ koncentracijų pokyčiams bulvių gumbuose ir vasarinių rapsų sẻklose bei kūlenose buvo nevienoda.

Reikšminiai žodžiai: bulvès, kompostai, cheminių elementų koncentracija, vasariniai rapsai. 